\title{
Y Shaped Colonic Duplication Mimicking Intestinal \\ Volkan Sarper Erikci $\odot$ Volvulus: A Case Report and Review of Literature
}

\author{
intestinal Volvulusu Taklit Eden Y Şekilli Kolonik \\ Duplikasyon: Olgu Sunumu ve Literatür Incelemesi
}

\section{ABSTRACT}

Enteric duplications are rare congenital anomalies found anywhere from mouth to anus. Colonic duplications constitute about $13 \%$ of all enteric duplications. In this report a 6-year-old boy with chronic abdominal pain for a duration of last 2 years requiring intermittent hospital admissions was diagnosed as colonic duplication mimicking intestinal volvulus. Clinical findings are nonspecific and definitive diagnosis can only be made during surgical intervention and surgical treatment is advocated for all duplications. The topic is discussed under the light of relevant literature with a brief a brief literature review.

Keywords: Colonic duplication, intestinal volvulus, children

Öz

Enterik duplikasyonlar nadir anomaliler olup ağızdan anüse kadar herhangi bir yerde gözlenebilir. Kolonik duplikasyonlar enterik duplikasyonların \%13'ünü oluşturur. Bu çalışmada 2 yıldır devam eden kronik karın ağrılı 6 yaşında erkek çocuğu sunulmaktadır. Sık hastane yatışları mevcut olan olgumuzda intestinal volvulusu taklit eden kolonik duplikasyon saptanmıştır. Bu olgularda klinik bulgular nonspesifik olup kesin tanı ancak cerrahi girişim sırasında konulur ve cerrahi tedavi tüm duplikasyonlar için önerilmektedir. Konu hakkındaki literatür incelenerek kolonik duplikasyonlar gerekli bilgiler verilerek tartışılmaktadır.
Received: 12.10 .2020

Accepted: 13.11 .2020

Published Online: 30.04 .2021

Cite as: Erikçi VS. Y shaped colonic duplication mimicking intestinal volvulus: a case report and review of literature. İzmir Dr. Behçet Uz Çocuk Hast. Dergisi. 2021;11(1):108-12.

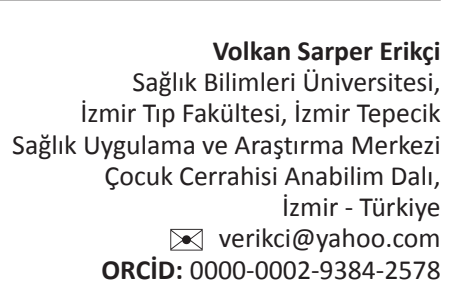

Anahtar kelimeler: Kolonik duplikasyon, intestinal volvulus, çocuklar

\section{INTRODUCTION}

Enteric duplications (“ED”) are rare congenital anomalies and can occur anywhere in the gastrointestinal tract from mouth to anus ${ }^{(1)}$. Sites of involvement include ileum (33\%), esophagus (20\%), colon (13\%), jejunum (10\%), stomach (7\%), and duodenum in $5 \%$ of cases (2-4). More than $80 \%$ of patients present before the age of 2 years and findings in presentations vary from case to case. These include nonspecific findings like; abdominal pain and mass, acute abdomen or intestinal obstruction like volvulus, or intussuception and rectal bleeding ${ }^{(5-7)}$. The aim of this study is to present a case with $Y$ shaped colonic duplication presenting like intestinal volvulus and to discuss the topic with regard to relevant literature and to give a brief literature review. CASE A 3-yearold boy with a complaint of abdominal pain and vomiting was admitted to our clinic. He had a chronic abdominal pain for a duration of last 2 years requiring intermittent hospital admissions. The physical examination revealed that the boy was dehydrated and tachycardic. Resuscitation with IV fluid and electrolyte was commenced promptly. He had a moderate abdominal distention and laboratory tests were within normal range. Standing abdominal X-ray showed large air collection at the middle abdomen with multiple gas filled, grossly dilated bowel loops (Figure 1). Abdominal ultrasonography (US) reported a diffuse collection of fluid in the abdominal cavity at the region of hepatorenal, pelvic, and superior to bladder. Urgent computerized tomography (CT) scan of the abdomen revealed findings compatible with an intestinal volvulus located periumbilically at the right of mid abdominal line (Figure 2). Emergent laparotomy was performed and a tubular bowel seg-

(c) Copyright İzmir Dr. Behçet Uz Children's Hospital. This journal published by Logos Medical Publishing. Licenced by Creative Commons 4.0 International (CC BY) 


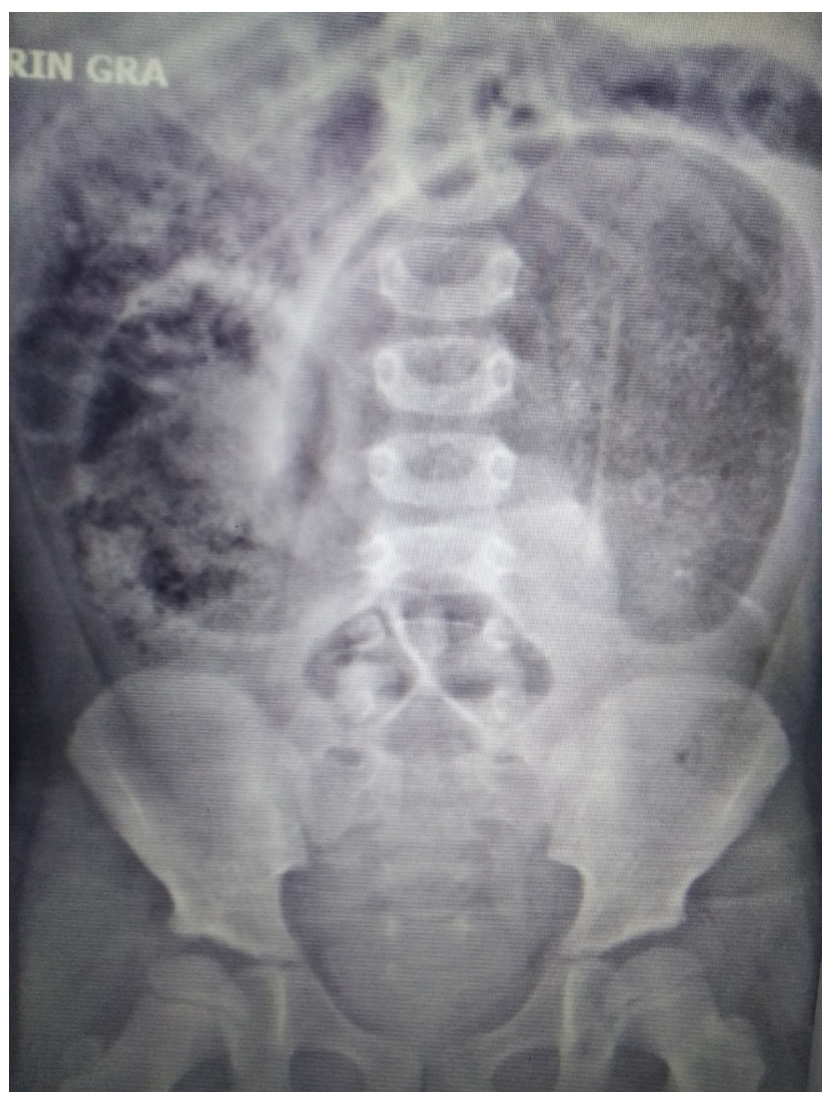

Figure 1. Standing abdominal X-ray showing large air collection in the abdomen with multiple gas filled, grossly dilated bowel loops.

ment originating from ascending colon, measuring $21.5 \times 5 \times 8 \mathrm{~cm}$ with a dilated blind end floating freely in the abdominal cavity together with hemorrhagic fluid collection were found. Duplicated colonic segment was found to be congested and twisted $360^{\circ}$ anticlockwise around mesentery with caecum and appendix found in the right lower quadrant (Figure $3)$. After detorsion of the volvulus, in addition to an incidental appendectomy, resection of colonic duplicated segment was performed with the aid of linear $6 \mathrm{~cm}$ stapler device (Figures 4 and 5). A second suture layer with 4/0 polyglicolic acid was performed for reinforcement of stapler suture line at the resection site in the native colon. Histopathologic examination of the excised specimen revealed a colonic duplication containing all layers of large intestine without evidence of ectopic or abnormal tissue. For a possibility of concomitant urinary, cardiac and vertebral anomalies, the patient was evaluated accordingly

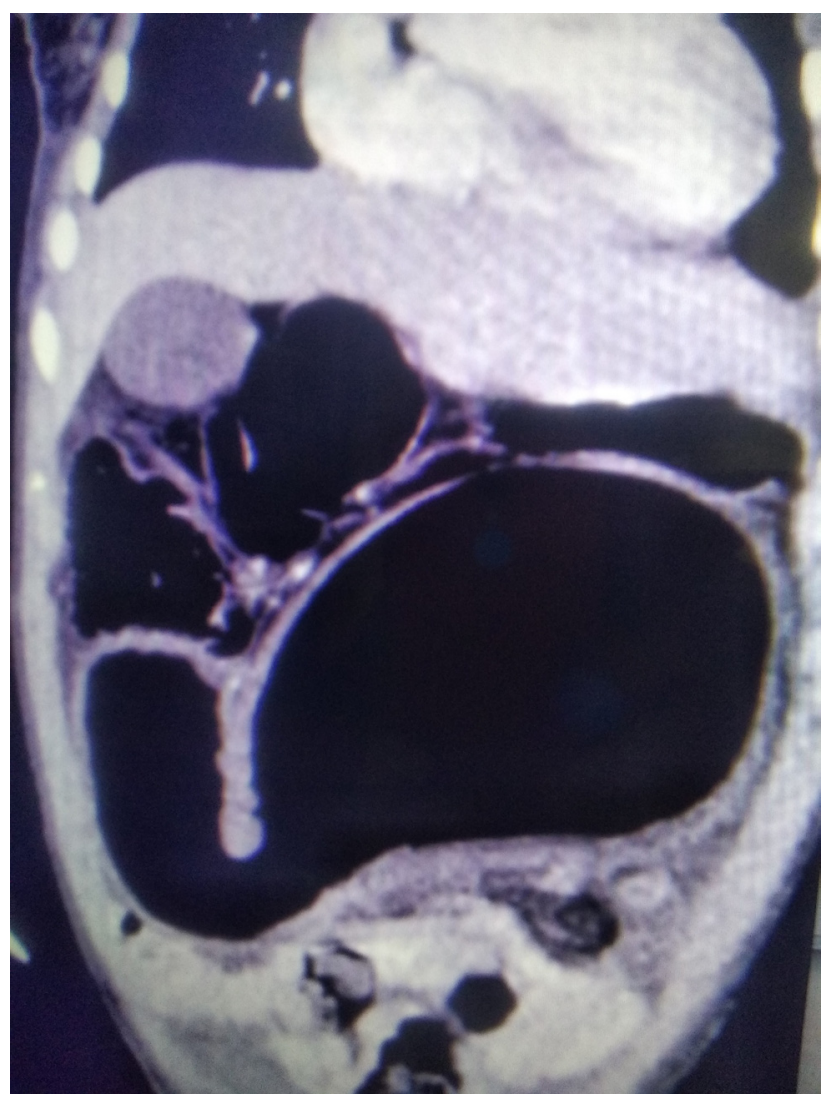

Figure 2. Abdominal CT scan showing intestinal volvulus in the abdominal cavity.

and had no accompanying anomalies. The child did well post operation and was commenced on oral feeds on the 4th postoperative day and discharged on 7th postoperative day. He is disease free and gaining weight with no symptoms.

\section{DISCUSSION}

Alimentary tract duplications in children are rare congenital anomalies commonly seen under the age of 2 years as an acute abdomen or bowel obstruction $(8,9)$. The incidence of gastrointestinal duplications is 1 in 4500 autopsies ${ }^{(10)}$. The first report of ED was made by Calder in 1733 and the term "Duplications of the Alimentary Tract" was coined by Ladd in $1937^{(6,11)}$. In a meta analysis comprising 580 cases, it was found that $80 \%$ of lesions occured in the abdomen and $20 \%$ in the chest ${ }^{(12)}$. There are numerous terms for defining these masses including; enterogenous cysts, 


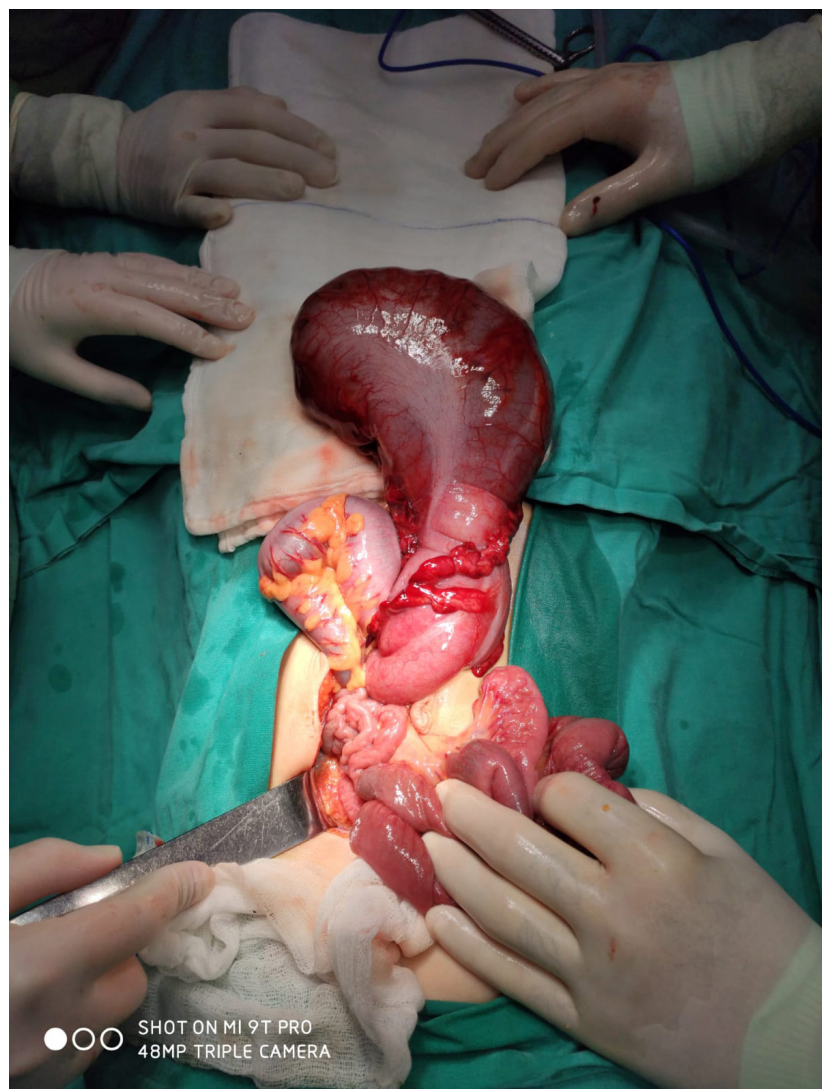

Figure 3. Peroperative view. Note the duplicated congested colonic segment was detorsed.

giant diverticula, ileal or jejuna duplex, and unusual meckel diverticula ${ }^{(7)}$. The etiology of EDs is still unclear and it is believed that it occurs between 4th and 8th weeks of gestation ${ }^{(13)}$. There are several proposed theories to explain the pathophysiology of EDs suggesting that the origin of ED can be multifactorial. These are the theories of split notochord, luminal recanalisation, partial twinning, persistent embryonic diverticula, and intrauterine vascular accident (2,3,14-16). EDs have 3 characteristics in common; epithelial lining containing alimentary mucosa, smooth muscle envelope, and close attachment with gastrointestinal tract showing common wall ${ }^{(13)}$. Structurally, they can be cystic in $80 \%$ and tubular in $20 \%$ of cases. Cystic duplications are not related to adjacent intestinal lumen whereas tubular lesions may be related to adjacent colonic lumen adjacent as in our case ${ }^{(17)}$. It has been reported that ectopic tissue is present in $25-30 \%$ of duplicated specimens and most

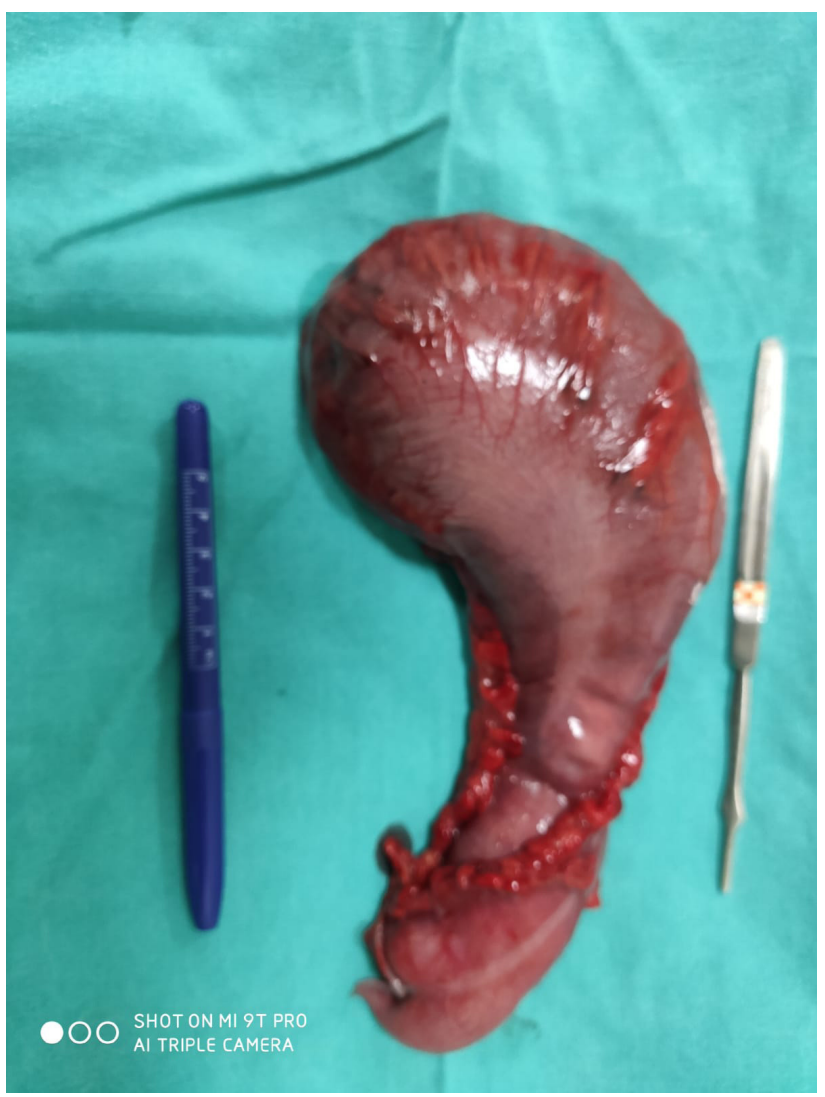

Figure 4. Postoperative view of the resected duplicated colonic segment.

common types of ectopic tissues are gastric followed by pancreatic tissue ${ }^{(6)}$. Presentation of colonic duplication is variable and asymptomatic in $10 \%$ of patients and can be discovered accidentally at surgery ${ }^{(18)}$. Vague abdominal pain and distention, vomiting, constipation or failure to thrive may be observed. As an emergency setting, the children may present with an acute intestinal obstruction due to intussuception or volvulus as in the presented case. If there is ectopic gastric tissue in the epithelial lining of duplicated colon, rectal bleeding may be observed. Extra gastrointestinal anomalies including genital, urinary or cardiovascular systems have been reported in $80 \%$ of patients with colonic duplications ${ }^{(19,20)}$. Our patient did not reveal any finding related to these systems. Imaging findings may be helpful in diagnosing colonic duplications in children. Plain abdominal X-ray is usually nonspecific and shows features of intestinal obstruction and air filled intestinal loops. 


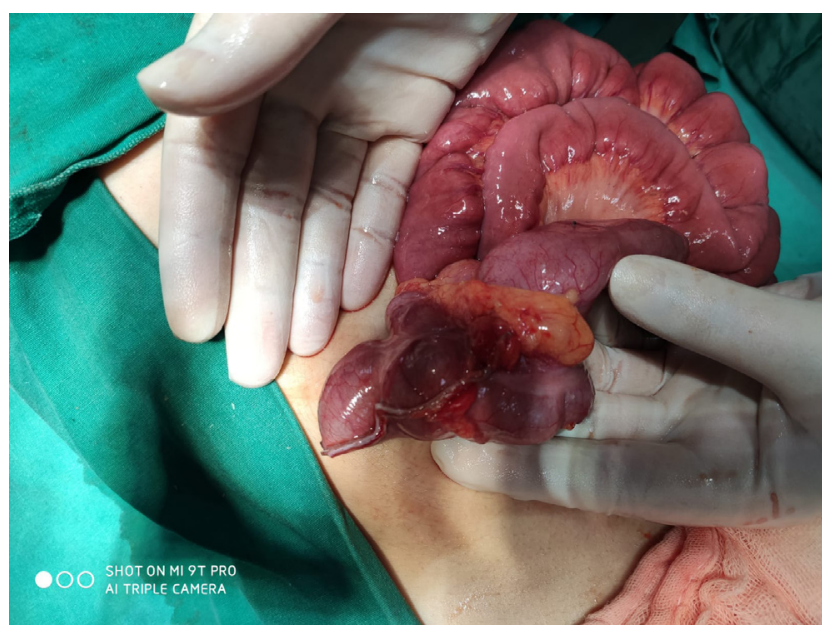

Figure 5. Postoperative view. Note resection of colonic duplication and an incidental appendectomy was performed.

Ultrasonography ("US") is the imaging modality of choice in the diagnosis of ED but is operator dependent. Classical findings of uncomplicated cystic EDs are the presence of a cyst adjacent to the gut with double-wall or muscular sign (gut signature sign) but US may be non-helpful in diagnosing tubular duplications ${ }^{(13)}$. Sonographic finding in the presented case is nonspecific and includes massive abdominal fluid collection in the abdominal cavity. Due to ionizing radiation computerized tomography (CT) is not typically performed to evaluate the EDs but may depict location and extension of duplication and anatomical relationship with surrounding structures as well as complications like volvulus ${ }^{(13)}$. CT finding in our case was an intestinal volvulus necessitating urgent surgical intervention. The treatment in colonic duplications is surgical excision of the duplicated intestinal segment. The aims of surgery are to relieve the symptoms, to eliminate the risks of complications like volvulus, intussuception or bleeding from an ectopic gastric mucosa. Resection of duplicated colonic segment can also decrease the risk of adenocarcinoma because the occurence of adenocarcinoma in the duplicated colon is higher than duplications located at any other locations ${ }^{(21,22)}$. Other surgical treatment options especially in extensive tubular colonic duplications include cyst marsupialisation, partial cystectomy, and mucosal stripping. In conclusion, colonic duplications especially $Y$ shaped lesions in children may be a challenge for clinicians with regard to not the surgical treatment but the clinical diagnosis because these cases usually can not be diagnosed usually without surgical intervention. Significant morbidity and even mortality may be observed if these patients are left untreated. A high index of suspicion is necessary to recognize this anomaly and clinicians should keep this entity in their minds in children with nonspecific complaints of gastrointestinal tract including abdominal pain, vomiting or intestinal obstruction and these children should be provided treatment and care promptly for an uneventful recovery.

\section{Conflict of Interest: None.}

Informed Consent: Obtained from the patient's relatives.

\section{REFERENCES}

1. Mirshemirani A, Roshanamir F, Shayeghi SH, Mohajerzadeh L, Hasas-yeganeh SH. Diphallus with imperforate anus and complete duplication of rectosigmoid colon and lower urinary tract. Iran J Pediatr. 2010;20:229-32.

2. Hur J, Yoon CS, Kim MJ, Kim OH. Imaging features of gastrointestinal tract duplications in infants and children: from esophagus to rectum. Pediatr Radiol. 2007;37:691-9. https://doi.org/10.1007/s00247-007-0476-3

3. Berrocal T, Hidalgo P, Gutiérrez J, De Pablo L, RodriguezLemos R. Imagen radiológica de las duplicaciones del tubo digestivo. Radiologia 2004;46:282-92. https://doi.org/10.1016/S0033-8338(04)77978-3

4. Sharma S, Yadav AK, Mandal AK, Zaheer S, Yadav D, et al. Enteric duplication cysts in children: a clinicopathological dilemma. J Clin Diagn Res 2015; 9: 8-11. https://doi.org/10.7860/JCDR/2015/12929.6381

5. Liaqat $\mathrm{N}$, Latif $\mathrm{T}$, Khan FA, Iqbal A, Nayyar SI, et al. Enteric duplication in children: a case series. Afr J Paediatr Surg 2014;11:211-4.

https://doi.org/10.4103/0189-6725.137327

6. Keckler SJ, Holcomb GW. Alimentary tract duplications. In: Holcomb GW, Murphy JP eds Ashcraft's Paediatric Surgery. 5th ed. Philadelphia: Sanders Elsevier 2010. p.517-25. https://doi.org/10.1016/B978-1-4160-6127-4.00040-9

7. Lund DP. Alimentary tract duplications. In: Grosfeld JL, O'Neill JA, Fonkalsrud EW, Coran AG, eds. Paediatric Surgery. 6th ed. Philadelphia: Mosby Elsevier, 2006. p.1389-99. https://doi.org/10.1016/B978-0-323-02842-4.50091-7

8. Kekez T, Augustin G, Hrstic I, Smud D, Majerovic M, et al. Colonic duplication in an adult who presented with chronic constipation attributed to hypothyroidism. World J Gastroenterol 2008;14:644-6. https://doi.org/10.3748/wjg.14.644

9. Merrot T, Anastasescu R, Pankevych T, Tercier S, Alessandrini $P$, et al. Duodenal duplications: clinical characteristics, emb- 
ryological hypothesis, histological findings, treatment. Eur J Pediatric Surg. 2006;16:18-23. https://doi.org/10.1055/s-2006-923798

10. Tabari AK. Complete colonic duplication in children. Caspian J Intern Med 2012;3(2):436-9.

11. Ladd WE. Duplications of the alimentary tract. South Med J 1937; 30: 363-71. https://doi.org/10.1097/00007611-193704000-00002

12. Heiss K. Intestinal duplications. In: Oldham KT, Colombani PM, Foglia RP, eds. Surgery of infants and children: scientific principles and practice. Philadelphia: Lippicott-Raven; 1997. p.1265-76.

13. Nebot CS, Salvador RL, Palacios EC, Aliaga SP, Pradas VI. Enteric duplication cysts in children: varied presentations, varied imaging findings.

14. Macpherson RI. Gastrointestinal tract duplications: clinical, pathologic, etiologic, and radiologic considerations. Radiographics 1993;13:1063-80.

https://doi.org/10.1148/radiographics.13.5.8210590

15. Letelier AM, Barria CM, Beltran MS, Marcelo A, Moreno CH. Duplicacion intestinal: Diagnostico y tratamiento de una condicion inusual. Rev Chil Cir 2009;61:171-5. https://doi.org/10.4067/S0718-40262009000200011

16. Palacios A, De Vera M, Martinez-Escoriza JC. Prenatal sonographic findings of duodenal duplication: case report. J Clin
Ultrasound 2013; 41(Suppl1): 1-4.

https://doi.org/10.1002/jcu.22007

17. Stefanidis K, Lappas I, Kolofousi C, Kalogeropoulos I. A rare presentation of colonic duplication cyst: report of a case and review of literature. JBR-BTR 2012;95:71-3. https://doi.org/10.5334/jbr-btr.92

18. Poulson EC, Mahmoud NN. Sigmoid colon duplication cysts. Am Surg 2008; 74: 250-2. https://doi.org/10.1177/000313480807400315

19. Kaur N, Nagpal K, Sodhi P, Minocha VR. Hindgut duplicationcase report and literature review. Pediatr Surg Int 2004;20:640-2.

https://doi.org/10.1007/s00383-004-1248-x

20. Blickman JG, Rieu PH, Buonomo C, Hoogeveen YL, Boetes C. Colonic duplications: clinical presentation and radiologic features of five cases. Eur J Radiol. 2006;59:14-9. https://doi.org/10.1016/j.ejrad.2006.03.012

21. Inoue $Y$, Nakamura $H$. adenocarcinoma arising in colonic duplication cysts with calcification: CT findings of two cases. Abdom Imaging 1998; 23: 135-7. https://doi.org/10.1007/s002619900305

22. Mourra N, Chafai N, Bessoud B, Reveri V, Werbrouck A, et al. Colorectal duplication in adults: report of seven cases and review of the literature. J Clin Pathol 2010; 63: 1080-3. https://doi.org/10.1136/jcp.2010.083238 